Available online at GSC Online Press Directory

GSC Biological and Pharmaceutical Sciences

e-ISSN: 2581-3250, CODEN (USA): GBPSC2

Journal homepage: https://www.gsconlinepress.com/journals/gscbps

(RESEARCH ARTICLE)

\title{
Nutritional and microbiological qualities of pumpkin (Cucurbita pepo) seed composite flours
}

\author{
Christian Chukwuemeka Ike ${ }^{1, *}$, Peace Chika Emeka-Ike ${ }^{2}$ and Happiness Odinakachi Ogwuegbu ${ }^{3}$ \\ ${ }^{1}$ Department of Biological Sciences (Microbiology Programme), College of Basic and Applied Sciences, Rhema University, \\ Nigeria, P.M.B. 7021 Aba, Abia State. \\ ${ }^{2}$ Department of Food Science and Technology, Imo State University, Owerri, P.M.B. 2000 Owerri, Imo State, Nigeria. \\ ${ }^{3}$ Department of Microbiology, Abia State University Uturu, P.M.B. 2000 Uturu, Abia State, Nigeria.
}

Publication history: Received on 13 July 2020; revised on 06 September 2020; accepted on 09 September 2020

Article DOI: https://doi.org/10.30574/gscbps.2020.12.3.0222

\begin{abstract}
The nutritional and microbiological qualities of pumpkin (Cucurbita pepo) seed composite flours were studied using standard nutrient assessment and microbiological methods. Proximate and nutrient content analysis showed that pumpkin (Cucurbita pepo) seed flour (PSF) had low moisture (6.48 $\pm 0.72 \%)$ and starch content $(19.75 \pm 2.47 \%)$ with high ash (5.92 $\pm 0.81 \%)$, fat (33.12 $\pm 2.20 \%)$, fibre $(7.24 \pm 0.64 \%)$ and protein $(27.05 \pm 2.01 \%)$ contents over wheat flour (WF1). Mineral and peroxide values were high in pumpkin seed flour (PSF) than wheat flour (WF1). The blended flours (CF1-CF6) recorded higher mineral (mg/100 g) and peroxide (meg/kg) contents than wheat flour (WF1) - the control; with CF6 (60\% pumpkin) having the highest values (Ca-95.40 \pm 1.63 , K-688.40 \pm 2.91, Fe-6.76 $\pm 0.05, \mathrm{Zn}-10.61 \pm 1.06$ and peroxide - 3.24 \pm 0.02 ). Bacterial and fungal counts (CFU/g) of blended flours ranged from $2.83 \times 10^{3} \pm 0.09-3.15 \times 10^{3}$ \pm 0.52 and $3.59 \times 10^{2} \pm 1.81-3.92 \times 10^{2} \pm 1.12$ respectively. WF1 flour recorded the highest bacterial and fungal counts while CF6 recorded the least bacterial and fungal counts. Four (4) bacterial and three (3) fungal isolates were identified to include Bacillus species, Pseudomonas aeruginosa, Staphylococcus aureus, Escherichia coli, and Penicillium species, Mucor species, Aspergillus species respectively. Due to the high nutritional contents and reduced microbial counts of the blends, inclusion of pumpkin seed flour in supplemented products should be encouraged so as to enhance nutritional requirements and eradicate malnutrition among individuals especially infants and children.
\end{abstract}

Keywords: Pumpkin (Cucurbita pepo) seed; Proximate; Mineral; Peroxide; Microbial.

\section{Introduction}

Pumpkin (Cucurbita pepo) is a monoecious, annual plant of the Cucurbitaccae family. Pumpkin is botanically classified as a fruit but widely regarded as a vegetable. Pumpkin and their seeds are native to America and various species are found across the North, South and Central America. Pumpkin varies greatly in form, but is generally oblong or ovoid in shape. The rind is smooth and varies in colour between cultivars. Some fruits are dark green, pale green, orange-yellow, white, red or grey. Pumpkin seeds also known as pepitas are flat, dark green seeds encased in a yellow-white husk [1].

The pumpkin seed contain substantial amounts of macro and micro minerals such as phosphorus, magnesium, potassium, calcium, zinc, iron and sodium [2]. Micro constituents are required in much smaller amounts such as copper, zinc, manganese, cobalt, and iron and are known as trace elements [3]. Minerals are important for enzymatic activities

\footnotetext{
${ }^{*}$ Corresponding author: Ike Christian Chukwuemeka

Department of Biological Sciences (Microbiology Programme), College of Basic and Applied Sciences, Rhema University, Nigeria P.M.B. 7021 Aba, Abia State.
} 
and normal physiological functions in the human body. In addition to protein, fat, and carbohydrates, the body requires inorganic nutrients such as sodium, calcium, potassium, and phosphorus in available form [4].

According to [1] and [5], pumpkin seed is a good source of essential fatty acids. [1] also showed that Curcubita pepo seeds are rich in oil with the oil containing four dominant fatly acids which are palmitic, stearic, oleic, and linoleic. This high fat content reduces microbial deterioration, which enhances shelf life stability of the products [5].

Although still not widely used in the food industry, pumpkin is consumed in homes worldwide in dishes such as pumpkin bread, soup, pie, etc. The fruits are consumed as vegetable or dessert and seeds as nuts and to a lesser extent as cooking oil [7]. In Eastern Nigeria, pumpkin is mainly grown for leaves, and edible pulp. The seeds are less utilized but occasionally are used as snacks after roasting. Hence the seeds are discarded, leaving some for the next planting season. Pumpkin seed is a good source of iron, zinc, essential fatty acids, potassium and magnesium [1; 5].

The serious consequences of malnutrition particularly among infants and children form a primary roadblock to social and economic development. Research has shown that the seeds have antioxidant effects [8]. In addition to the good nutritional and health benefits of Cucurbita seeds, they are cheap and are widely distributed [9]. Pumpkin can be processed into flour which has a longer shelf life and good microbial safety than its natural vegetable and fruits. Processing methods are employed mostly to preserve and improve the organoleptic properties of foods, microbial quality and equally to enhance shelf life [10]. Preservation of vegetable and fruits is an excellent way to curb postharvest losses which are major challenges in sub-Sahara African countries $[11 ; 12]$. Recently more attention has been focused on the utilization of underutilized agricultural products. Obviously such utilization would contribute to maximizing available resources and could result in the production of various new food products. The rich nutrition base of pumpkin can be tapped to improve the nutritional quality of baked products, soup and sauces [11].

Consumers are becoming more conscious of healthy eating and prefer locally grown foods that support healthy lifestyles more than imported foods in order to conveniently cut-back on saturated fat, cholesterol, sodium and calories [13]. Therefore, this work is aimed at studying the nutritional and microbiological qualities of pumpkin (Cucurbita pepo) seed composite flours.

\section{Material and methods}

\subsection{Processing of pumpkin seed flour}

Pumpkin (Cucurbita pepo) seeds were extracted from the fruits, washed, sun-dried and manually decorticated as shown in figure 1 . The seeds were screened to remove all particles, dried overnight in the oven at $50{ }^{\circ} \mathrm{C}$. The seeds (890 g) were crushed using an electric grinder (Super Intermet blender S1-462 model). The crushed sample was dried at regulated temperature and ground to a fine powder (to pass through a 355 MICS sieve) in order to obtain about $750 \mathrm{~g}$ flour and about $140 \mathrm{~g}$ waste. The flour was packaged in an air-tight container and kept in a refrigerator until it is needed for analysis.

\subsection{Proximate analysis}

Proximate analyses of the flour involving moisture, ash, fat, fibre, protein, and carbohydrate contents of pumpkin (Cucurbita pepo) seed composite flours were carried out using standard methods as described by [14].

\subsection{Determination of minerals}

The method of [14] was adopted in the determination of calcium, potassium, iron and zinc contents of pumpkin (Cucurbita pepo) seed composite flours. Calcium (Ca), iron (Fe) and zinc ( $\mathrm{Zn}$ ) were determined by atomic absorption spectrophotometer - AAS, (Alpha 4 model, Buck Scientific Ltd, USA) while potassium (K) was determined using atomic emission spectrometer (200-A model, Buck Scientific Ltd UK).

\subsection{Peroxide value determination}

The method described by [15] was adopted in the determination of peroxide value of pumpkin (Cucurbita pepo) seed composite flours. 


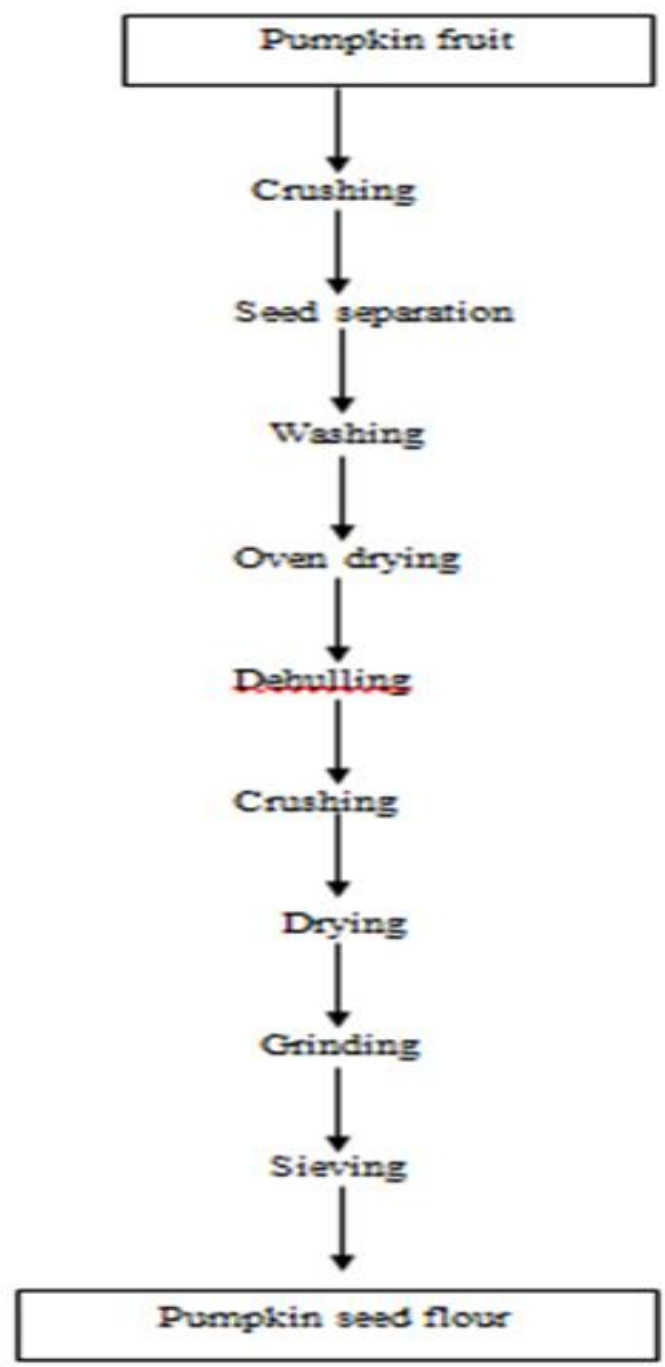

Figure 1 Flow diagram for the preparation of pumpkin seed flour

\subsection{Microbiological analyses of wheat and blended flours}

Wheat flour (WF1) and blended flours from mixture of pumpkin seed flour (PSF) and WFI at varying proportions to form composites were stored in air-tight glass container, and were analyzed for bacterial and fungal counts using spread plate method as described by [16]. Ten fold serial dilutions of flour samples were done using sterile peptone water as diluent. One gramme $(1 \mathrm{~g})$ each of sample was aseptically transferred into a sterile test tube containing nine milliliter $(9 \mathrm{~mL})$ of sterile peptone water, stirred with sterile glass rod and was shaken vigorously to ensure adequate disengagement of microorganisms to obtain $10^{-1}$ dilution. Serial dilutions of the homogenates were continued and made step-wisely till the fifth (5th) tube, to obtain dilutions of $10^{-2}$ to $10^{-5}$. Spread plate techniques of [16] were used to enumerate bacteria and fungi in the samples and each dilution was plated in replicates using plate count agar for mean bacterial count and fortified sabouraud dextrose agar (SDA) for mean fungal count. The plates were incubated at $35 \pm 2$ ${ }^{\circ} \mathrm{C}$ for 72 hours for mean bacterial counts and $25 \pm 2{ }^{\circ} \mathrm{C}$ for 120 hours for mean fungal counts. Pure bacterial isolates were identified using cultural, morphological and biochemical characterization. Identification of the bacteria to genera level was based on the schemes of [17]. The purified fungal isolates were identified on the basis of macroscopic and microscopic characteristics by slide culture technique and lactophenol staining. The scheme of [18] was used for the identification.

\subsection{Statistical analyses}

All obtained data in this study were analyzed using analysis of variance (ANOVA). Descriptive statistics in form of mean, standard deviation and Duncan post hoc were also used to assess the data, and analyses were done using SPSS version 20 (Statistical Product and Service Solutions). 


\section{Results}

\subsection{Proximate composition}

Results of the proximate composition of wheat, pumpkin seed and composite flours are shown in Table 1 . The moisture content of blended flours ranged from $9.25 \pm 1.22 \%$ to $12.13 \pm 1.46 \%$, while PSF and WF1 had $6.48 \pm 0.72 \%$ and 13.30 $\pm 1.58 \%$ respectively (Table 1$)$. WF1 had the highest value for moisture content $(13.30 \pm 1.58 \%)$, while PSF had the least value for moisture content ( $6.48 \pm 0.72 \%)$. The ash content of blended flours ranged from $2.20 \pm 0.18 \%$ to $4.12 \pm 1.05 \%$, while PSF and WF1 had $5.92 \pm 0.81 \%$ and $1.30 \pm 0.06 \%$ respectively (Table 1 ). PSF had the highest value for ash content (5.92 $\pm 0.81 \%)$, while WF1 had the least value for ash content $(1.30 \pm 0.06 \%)$. The fat content of blended flours ranged from $7.41 \pm 1.92 \%$ to $21.16 \pm 1.30 \%$, while PSF and WF1 had $33.12 \pm 2.20 \%$ and $0.90 \pm 0.52 \%$ respectively (Table 1 ). PSF had the highest value for fat content $(33.12 \pm 2.20 \%)$, while WF1 had the least value for fat content $(0.90 \pm 0.52 \%)$. The fibre content of blended flours ranged from $1.93 \pm 0.24 \%$ to $6.34 \pm 0.41 \%$, while PSF and WF1 had $7.24 \pm 0.64 \%$ and 0.36 $\pm 0.19 \%$ respectively (Table 1$)$. PSF had the highest value for fibre content $(7.24 \pm 0.64 \%)$, while WF1 had the least value for fibre content $(0.36 \pm 0.19 \%)$. The protein content of blended flours ranged from $13.89 \pm 1.52 \%$ to $21.11 \pm 1.92 \%$, while PSF and WF1 had $27.05 \pm 2.01 \%$ and $10.71 \pm 1.36 \%$ respectively (Table 1). PSF had the highest value for protein content $(27.05 \pm 2.01 \%)$, while WF1 had the least value for protein content $(10.71 \pm 1.36 \%)$. The carbohydrate content of blended flours ranged from $36.33 \pm 2.71 \%$ to $66.11 \pm 2.80 \%$, while PSF and WF1 had $19.75 \pm 2.45 \%$ and $73.88 \pm 3.01 \%$ respectively (Table 1). WF1 had the highest value for carbohydrate content (73.88 $\pm 3.01 \%)$, while PSF had the least value for carbohydrate content $(19.75 \pm 2.45 \%)$. All values obtained in this study when compared were statistically significant $(\mathrm{p}<0.05)$.

Table 1 Proximate composition of wheat, pumpkin seed and composite flours

\begin{tabular}{lllllll}
\hline Nutrients & WF1 & PSF & \multicolumn{2}{l}{ Composite flours (\%) } & & \\
& & & CF2 & CF4 & CF5 & CF6 \\
\hline Moisture (\%) & $13.30 \pm 1.58^{\mathrm{a}}$ & $6.48 \pm 0.72^{\mathrm{d}}$ & $12.13 \pm 1.46^{\mathrm{ab}}$ & $10.81 \pm 1.52^{\mathrm{abc}}$ & $10.03 \pm 1.35^{\mathrm{bc}}$ & $9.25 \pm 1.22^{\mathrm{c}}$ \\
Total ash (\%) & $1.30 \pm 0.06^{\mathrm{d}}$ & $5.92 \pm 0.81^{\mathrm{a}}$ & $2.20 \pm 0.18^{\mathrm{cd}}$ & $3.17 \pm 0.43^{\mathrm{bc}}$ & $3.60 \pm 0.59^{\mathrm{b}}$ & $4.12 \pm 1.05^{\mathrm{b}}$ \\
Fat (\%) & $0.90 \pm 0.52^{\mathrm{f}}$ & $33.12 \pm 2.20^{\mathrm{a}}$ & $7.41 \pm 1.92^{\mathrm{e}}$ & $14.98 \pm 1.23^{\mathrm{d}}$ & $17.82 \pm 1.15^{\mathrm{c}}$ & $21.16 \pm 1.30^{\mathrm{b}}$ \\
Crude fibre (\%) & $0.36 \pm 0.19^{\mathrm{f}}$ & $7.24 \pm 0.64^{\mathrm{a}}$ & $1.93 \pm 0.24^{\mathrm{e}}$ & $3.84 \pm 0.37^{\mathrm{d}}$ & $4.99 \pm 0.15^{\mathrm{c}}$ & $6.34 \pm 0.41 \mathrm{~b}$ \\
Crude protein (\%) & $10.71 \pm 1.36^{\mathrm{e}}$ & $27.05 \pm 2.01^{\mathrm{a}}$ & $13.89 \pm 1.52^{\mathrm{d}}$ & $17.01 \pm 1.75^{\mathrm{c}}$ & $19.18 \pm 1.86^{\mathrm{bc}}$ & $21.11 \pm 1.92^{\mathrm{b}}$ \\
Carbohydrate (\%) & $73.88 \pm 3.01^{\mathrm{a}}$ & $19.75 \pm 2.47^{\mathrm{f}}$ & $66.11 \pm 2.80^{\mathrm{b}}$ & $52.16 \pm 2.66^{\mathrm{c}}$ & $45.71 \pm 2.54^{\mathrm{d}}$ & $36.33 \pm 2.71^{\mathrm{e}}$ \\
\hline
\end{tabular}

Legend: WF1 = 100\% Wheat flour, CF2 = 20\% Pumpkin seed flour, CF4 = 40\% Pumpkin seed flour, CF5 = 50\% Pumpkin seed flour, CF6 = 60\% Pumpkin seed flour, PSF $=$ Pumpkin seed flour. Values are given as mean \pm SD. Within rows, values followed by the same alphabets are not significantly different but those followed by different alphabets are significantly different $\mathrm{p}<0.05$.

\subsection{Mineral content}

Results of the mineral content of wheat, pumpkin seed and composite flours are shown in Table 2. The calcium content of blended flours ranged from $49.80 \pm 1.43 \mathrm{mg} / 100 \mathrm{~g}$ to $95.40 \pm 1.63 \mathrm{mg} / 100 \mathrm{~g}$, while PSF and WF1 had $140.50 \pm 2.19$ $\mathrm{mg} / 100 \mathrm{~g}$ and $26.30 \pm 1.02 \mathrm{mg} / 100 \mathrm{~g}$ respectively (Table 2$)$. PSF had the highest value for calcium content $(140.50 \pm 2.19$ $\mathrm{mg} / 100 \mathrm{~g}$ ), while WF1 had the least value for calcium content $(26.30 \pm 1.02 \mathrm{mg} / 100 \mathrm{~g})$. The potassium content of blended flours ranged from $368.30 \pm 2.46 \mathrm{mg} / 100 \mathrm{~g}$ to $688.40 \pm 2.91 \mathrm{mg} / 100 \mathrm{~g}$, while PSF and WF1 had $994.10 \pm 3.34 \mathrm{mg} / 100 \mathrm{~g}$ and $204.50 \pm 2.87 \mathrm{mg} / 100 \mathrm{~g}$ respectively (Table 2). PSF had the highest value for potassium content $(994.10 \pm 3.34$ $\mathrm{mg} / 100 \mathrm{~g})$, while WF1 had the least value for calcium content $(204.50 \pm 2.87 \mathrm{mg} / 100 \mathrm{~g})$. The iron content of blended flours ranged from $3.59 \pm 0.09 \mathrm{mg} / 100 \mathrm{~g}$ to $6.76 \pm 0.05 \mathrm{mg} / 100 \mathrm{~g}$, while PSF and WF1 had $8.14 \pm 0.15 \mathrm{mg} / 100 \mathrm{~g}$ and $2.38 \pm 0.19 \mathrm{mg} / 100 \mathrm{~g}$ respectively (Table 2$)$. PSF had the highest value for iron content $(8.14 \pm 0.15 \mathrm{mg} / 100 \mathrm{~g}), \mathrm{while}$ WF1 had the least value for iron content $(2.38 \pm 0.19 \mathrm{mg} / 100 \mathrm{~g})$. The zinc content of blended flours ranged from $3.64 \pm 1.18$ $\mathrm{mg} / 100 \mathrm{~g}$ to $10.61 \pm 1.06 \mathrm{mg} / 100 \mathrm{~g}$, while PSF and WF1 had $14.16 \pm 1.05 \mathrm{mg} / 100 \mathrm{~g}$ and $0.92 \pm 0.11 \mathrm{mg} / 100 \mathrm{~g}$ respectively (Table 2). PSF had the highest value for zinc content $(14.16 \pm 1.05 \mathrm{mg} / 100 \mathrm{~g})$, while WF1 had the least value for zinc content $(0.92 \pm 0.11 \mathrm{mg} / 100 \mathrm{~g})$. All values obtained in this study were statistically significant when compared $(\mathrm{p}<0.05)$. 
Table 2 Mineral content of wheat, pumpkin seed and composite flours

\begin{tabular}{|c|c|c|c|c|c|c|}
\hline \multirow[t]{2}{*}{ Minerals } & \multirow[t]{2}{*}{ WF1 } & \multirow[t]{2}{*}{ PSF } & \multicolumn{4}{|c|}{ Composite flours (\%) } \\
\hline & & & CF2 & CF4 & CF5 & CF6 \\
\hline Calcium (mg/100 g) & $26.30 \pm 1.02^{\mathrm{f}}$ & $140.50 \pm 2.19^{a}$ & $49.80 \pm 1.43^{e}$ & $72.60 \pm 1.76^{d}$ & $84.10 \pm 1.22^{c}$ & $95.40 \pm 1.63^{\mathrm{b}}$ \\
\hline Potassium (mg/100 g) & $204.50 \pm 2.87 \mathrm{f}$ & $994.10 \pm 3.34^{a}$ & $368.30 \pm 2.46^{\mathrm{e}}$ & $522.60 \pm 3.01^{d}$ & $600.20 \pm 3.27 \mathrm{c}$ & $688.40 \pm 2.91^{b}$ \\
\hline Iron $(\mathrm{mg} / 100 \mathrm{~g})$ & $2.38 \pm 0.19^{f}$ & $8.14 \pm 0.15^{\mathrm{a}}$ & $3.59 \pm 0.09 \mathrm{e}$ & $4.48 \pm 0.16^{\mathrm{d}}$ & $5.64 \pm 0.12^{\mathrm{c}}$ & $6.76 \pm 0.05^{b}$ \\
\hline Zinc (mg/100 g) & $0.92 \pm 0.11^{f}$ & $14.16 \pm 1.05^{\mathrm{a}}$ & $3.64 \pm 1.18 \mathrm{e}$ & $6.45 \pm 1.21^{\mathrm{d}}$ & $8.43 \pm 0.17 \mathrm{c}$ & $10.61 \pm 1.06^{b}$ \\
\hline
\end{tabular}

Legend: WF1 $=100 \%$ Wheat flour, CF2 $=20 \%$ Pumpkin seed flour, CF4 $=40 \%$ Pumpkin seed flour, CF5 = 50\% Pumpkin seed flour, CF6 = $60 \%$ Pumpkin seed flour, PSF $=$ Pumpkin seed flour. Values are given as mean \pm SD. Within rows, values followed by the same alphabets are not significantly different but those followed by different alphabets are significantly different $\mathrm{p}<0.05$.

\subsection{Peroxide value}

The results of peroxide values of flours are presented in Table 3. Peroxide values of blended flours ranged from $1.93 \pm 0.02 \mathrm{meq} / \mathrm{kg}$ to $3.24 \pm 0.02 \mathrm{meq} / \mathrm{kg}$. PSF had the highest peroxide value of $4.72 \pm 0.03 \mathrm{meq} / \mathrm{kg}$ while WF1 had the least peroxide value of $1.21 \pm 0.02 \mathrm{meq} / \mathrm{kg}$. Conclusively, the substitution of WF1 with different ratios of PSF during flour blending resulted in significant $(p<0.05)$ increase in peroxide value among the composites. Peroxide values obtained in this study were statistically significant $(\mathrm{p}<0.05)$ when compared.

Table 3 Peroxide values for wheat, pumpkin seed and composite flours

\begin{tabular}{|c|c|c|c|c|c|c|}
\hline \multirow[t]{2}{*}{ Sample } & \multicolumn{6}{|c|}{ Peroxide Value (meq/kg) } \\
\hline & WF1 & PSF & CF2 & CF4 & CF5 & CF6 \\
\hline Flour & $1.21 \pm 0.02^{\mathrm{f}}$ & $4.72 \pm 0.03^{a}$ & $1.93 \pm 0.02^{\mathrm{e}}$ & $2.63 \pm 0.01^{\mathrm{d}}$ & $2.91 \pm 0.03^{c}$ & $3.24 \pm 0.02^{\mathrm{b}}$ \\
\hline
\end{tabular}

\subsection{Microbiological analysis of wheat and blended flours}

The microbial qualities of blended flours are shown in Table 4. Bacterial and fungal counts (CFU/g)of blended flours ranged from $2.83 \times 10^{3} \pm 0.09$ to $3.15 \times 10^{3} \pm 0.52$ and $3.59 \times 10^{2} \pm 1.81$ to $3.92 \times 10^{2} \pm 1.12$ respectively. WF1 flour recorded the highest bacterial and fungal (CFU/g)counts $\left(3.20 \times 10^{3} \pm 1.33 / 4.19 \times 10^{2} \pm 0.46\right)$, while CF6 recorded the least bacterial and fungal $(\mathrm{CFU} / \mathrm{g})$ counts $\left(2.83 \times 10^{3} \pm 0.09 / 3.59 \times 10^{2} \pm 1.81\right)$ respectively. There were significant differences $(\mathrm{p}<0.05)$ in microbial counts among various samples when compared.

Table 4 Microbiological results of wheat and composite flours

\begin{tabular}{lll}
\hline Samples & Bacteria (CFU/g) & Fungi (CFU/g) \\
\hline WF1 & $3.20 \times 10^{3} \pm 1.33^{\mathrm{a}}$ & $4.19 \times 10^{2} \pm 0.46^{\mathrm{a}}$ \\
$\mathrm{CF} 2$ & $3.15 \times 10^{3} \pm 0.52^{\mathrm{ab}}$ & $3.92 \times 10^{2} \pm 1.12^{\mathrm{b}}$ \\
$\mathrm{CF} 4$ & $3.01 \times 10^{3} \pm 0.44^{\mathrm{c}}$ & $3.80 \times 10^{2} \pm 1.60^{\mathrm{bc}}$ \\
$\mathrm{CF} 5$ & $2.90 \times 10^{3} \pm 1.35^{\mathrm{c}}$ & $3.76 \times 10^{2} \pm 0.76^{\mathrm{bc}}$ \\
$\mathrm{CF} 6$ & $2.83 \times 10^{3} \pm 0.09^{\mathrm{cd}}$ & $3.59 \times 10^{2} \pm 1.81^{\mathrm{c}}$ \\
\hline
\end{tabular}

Legend: WF1 $=100 \%$ Wheat flour, CF2 $=20 \%$ Pumpkin seed flour, CF4 $=40 \%$ Pumpkin seed flour, CF5 = 50\% Pumpkin seed flour, CF6 = 60\% Pumpkin seed flour, PSF $=$ Pumpkin seed flour. Values are given as mean \pm SD. Within columns, values followed by the same alphabets are not significantly different but those followed by different alphabets are significantly different $\mathrm{p}<0.05$. 


\section{Discussion}

\subsection{Proximate composition}

The addition of pumpkin seed flour (PSF) into wheat flour (WF1) had significant $(p<0.05)$ effect on moisture, total ash, fat, crude fibre, crude protein and carbohydrate contents either progressively or retrogressively. However, as the blending ratio of PSF into WF1 increased, the lower was the value of moisture content among blends. This substitution of WF1 with increasing ratios of PSF resulted in significant $(p<0.05)$ decrease in moisture content among blends as shown in Table 1. Inclusion of PSF into WF1 that resulted in retrogressive effect on moisture content was advantageous because reduction in moisture content will reduce the proliferation of spoilage organisms especially mold, thus, improving the shelf stability of the product [19]. Therefore, results obtained in Table 1 for moisture content were statistically significant $(p<0.05)$ and in agreement with the reports of $[19 ; 20 ; 21 ; 22 ; 23 ; 24 ; 25]$. [26] reported that pumpkin flour has a good keeping quality and long shelf life due to its low moisture content and water activity. The relatively low moisture content is an indication of storage stability and could produce a more shelf stable product. Flours with moisture content above $14 \%$ are not stable at room temperature and as such organisms present in them will start growing, thus producing off odours and flavours [27].

Conversely, the addition of PSF into WF1 had significant but progressive $(p<0.05)$ effect on ash, fat, crude fibre and protein contents among the blends. Thus, as the blending ratio of PSF into WF1 increased, the higher were the values of ash, fat, crude fibre and protein contents among blends. This substitution of WF1 with increasing ratios of PSF resulted in progressive but significant $(p<0.05)$ increase in ash, fat, crude fibre and protein contents among blends as shown in Table 1.

The results obtained in Table 1 for ash content were statistically significant $(p<0.05)$ and in agreement with the reports of $[24 ; 25 ; 26]$. The increase in ash content among the blends could be attributed to the higher nutritive values of pumpkin seed flour (PSF) over wheat flour (WF1) as were reported by [20] and [28]. The higher nutritive values of PSF is the reason for the high analytical values recorded in ash, fat, fibre and protein as indicated in Table 1 above, which was in agreement with [29]. The ash content of a food sample gives an idea of the mineral elements present in the food. Ash content of a sample is a reflection of minerals it contains; hence pumpkin seeds are expected to be rich in minerals. It indicates the composition of inorganic constituents after organic materials (fats, proteins and carbohydrates) and moisture have been removed by incineration. It is essentially the mineral content of a food sample. Sample with high ash contents is expected to have high concentration of various mineral elements, which are expected to speed up metabolic processes, improve growth and development.

The results in Table 1 for fat content were statistically significant $(p<0.05)$ and in agreement with the reports of [24; 25; 26]. The progressive high fat levels obtained in the blends could be as a result of high nutritive contents of pumpkin seed flour (PSF) over wheat flour (WF1) as were reported by [20] and [28]. The high fat content recorded in the blends reduces microbial deterioration, which enhances shelf life stability of the products [6]. According to [1] and [5], pumpkin seed is a good source of essential fatty acids. [1] also showed that Curcubita pepo seeds are rich in oil with the oil containing four dominant fatly acids which are palmitic, stearic, oleic, and linoleic. [22] also revealed that palmitic, oleic, linoleic and stearic acids were the main fatty acids found in pumpkin seeds. Fats are essential in diets as they increase the palatability of foods by absorbing and retaining their flavours and help in the transport of nutritionally essential fat-soluble vitamins [30].

Fibre contents of this study were statistically significant $(p<0.05)$ and in agreement with reports of [24; 25; 26]. The progressive high fibre contents obtained in the blends could be as a result of high nutritive contents of pumpkin seed flour over wheat flour as were reported earlier by [20] and [28]. Crude fibre contents of the blends increased as the level of PSF substitution increased. This may also be attributed to components such as pectin, cellulose, hemicelluloses, and lignin [11] and high crude fibre content of vegetables which had a greater effect on the pumpkin seed. Fibre containing foods are known to expand the inside walls of the colon, easing the passage of waste, thus making it an effective anti-constipation. It lowers cholesterol level in the blood and reduces the risk of various cancers [23]. Crude fibre slows down the release of glucose into the blood and decreases intercolonic pressure hence reducing the risk of colon cancer [31].

Protein contents followed same trend with ash, fat and fibre contents, which were significant $(\mathrm{p}<0.05)$ and correlated with reports of [24] and [25]. This increase in protein content among blends may be attributed to high nutritive contents of pumpkin seed flour over wheat flour as was reported earlier by [20] and [28]. Protein contents of the blends increased as the level of PSF substitution increased. This expected increase was the basis for formulating the blends such that the final product will not only have higher protein content but also higher protein quality. 
This substitution of WF1 with increasing ratios of PSF resulted in significant $(p<0.05)$ decrease in carbohydrate content among blends as shown in Table 1. However, as the blending ratio of PSF into WF1 increased, the lower was the value of carbohydrate content among blends. Inclusion of PSF into WF1 resulted in retrogressive effect on carbohydrate content which was significant $(p<0.05)$ among blends. The results obtained in Table 1 for carbohydrate content followed same trend with moisture content which was significant $(\mathrm{p}<0.05)$ and correlated with reports of [24; 25; 26]. These low carbohydrate contents in the blends could be as a result of pumpkin seed flour been not considered as potential source of carbohydrate when compared to the content of some conventional sources like cereals [23]. More so, this decrease in carbohydrate content of blends may be attributed to low starch contents of pumpkin seed flour over wheat flour as was reported by [24]. In addition, the decrease in carbohydrate content among blends could be associated with low starch content of PSF as shown in Table 1. PSF had low bulk density when compared with WF1 [32]. There is a linear correlation between carbohydrate content and bulk density, hence result of reduction in carbohydrate content among blends is a direct consequence of low bulk density of PSF. Lower bulk density in the blends compared with $100 \%$ wheat flour could be a result of reduction in carbohydrate content [33].

\subsection{Mineral content}

The addition of PSF into WF1 had significant $(p<0.05)$ effect on calcium, potassium, iron and zinc contents. However, as the blending ratio of PSF into WF1 increased, the higher was the value for calcium, potassium, iron and zinc contents. This substitution of WF1 with increasing ratios of PSF resulted in significant $(p<0.05)$ increase in calcium, potassium, iron and zinc contents among blends as shown in Table 2. Calcium contents obtained in the blends were progressive with high level additions of PSF into WF1 which increased as the level of PSF substitution increased. The inclusion of PSF into WF1 had significant $(p<0.05)$ effect on mineral contents (calcium, potassium, iron and zinc contents) among blends which were progressive with increasing level of additions of PSF into WF1. This increase in calcium, potassium, iron and zinc contents among blends may be attributed to rich mineral content of pumpkin seed flour [2]. The expected increase was the basis for formulating the blends such that the final product will have high nutritive quality. Calcium and potassium contents in this study were similar and in agreement with reports of [20; 28; 34]. Iron content results in the study were similar and correlated with reports of $[21 ; 25 ; 28 ; 35 ; 36]$, while zinc content results were in agreement with results of $[20 ; 23 ; 25 ; 36]$.

According to [2], minerals are important for enzymatic activity and normal physiological function in the human body. Calcium is important in the formation and maintenance of strong bones and teeth throughout the life cycle. It is also involved in blood clotting and aids in nerve impulse transmission, muscle contractions and contributes to cell permeability [37]. Potassium is important in maintaining the water balance in the body and controlling the composition of blood and other body fluids [38]. Iron is a functional component of haemoglobin and plays an important role in changes in some neurotransmitters in the brain and brain development [39]. Zinc is significant in growth, immunity, alcohol metabolism, sexual development and reproduction [38].

\subsection{Peroxide value}

As the blending ratio of PSF into WF1 increased, higher were the peroxide values among blended flours. Hence, the substitution of WF1 with increasing levels of PSF resulted in significant $(p<0.05)$ increase in peroxide values among blended flours as shown in Table 3. Peroxide values obtained in the blended flours were progressive with increasing level of additions of PSF into WF1. Peroxide values of the blended flours increased as the level of PSF substitution increased. The increase in peroxide values of the blended flours was as a result of high oil content of pumpkin seed flour as was recorded in Table 1 above. Results of peroxide values obtained in this study were statistically significant $(p<0.05)$ and correlated with the assertions of [25]. According to [40] more peroxide value is harmful for shelf life of products.

\subsection{Microbiological studies}

With the high microbial counts recorded in the results, there are indications of poor storage conditions for WF1 and poor processing quality for PSF and the composites. WF1 was observed to be sold from folded woven sacks which were often displayed open to attract customers in the market. The high oil content of pumpkin flour (PSF) over wheat flour (WF1) as was observed in Table 1 could contribute to the reduced microbial counts recorded among the blends. In this study, there is a clear correlation between the blending ratios and microbial counts. Hence, as the blending ratio increased, the recorded microbial counts also decreased. Oil is an inhibitory substance that limits growth of aerobic microorganisms. It functions by sealing up the air pores through which air could flow in to support growth of aerobic microorganisms, thereby creating an unconducive environment that is devoid of oxygen (anaerobic). Oil could also be used in preserving food and other edible items because of its negative tendencies in supporting microbial growth especially the aerobes [6]. 
The low moisture content of PSF over WF1 in Table 1 was another factor pointing towards the reduced microbial counts recorded in the blends. Both moisture content and microbial counts are directly proportional as the higher the blending ratio of PSF into WF1, the lower were the values for microbial counts. According to [41], the preservation of foods by drying is a direct consequence of removal or binding of moisture, without which microorganisms do not grow. Moisture content could also be described in terms of water activity $\left(\mathrm{a}_{\mathrm{w}}\right)$ which is referred to as water requirements of microorganisms in the environment. This concept is related to relative humidity (RH) as shown: $\mathrm{RH}=100 \times \mathrm{a}_{\mathrm{w}}$. Water activity plays a role with moisture content in the growth of microorganisms, as it is the available water for microbial growth.

Several microbes were isolated in this work to include: four (4) bacterial species (Bacillus species, Pseudomonas aeruginosa, Staphylococcus aureus, and Escherichia coli) and three (3) fungal species (Penicillium species, Mucor species and Aspergillus species). These isolates could be linked as either environmental contaminants, unhygienic processing contaminants or as inherent microflora. The results obtained in this study were in agreement with the reports of [25; 42; 43]. According to [6], Bacillus species, Pseudomonas aeruginosa, Penicillium species, Mucor species and Aspergillus species were reported as soil/ environmental contaminants, Staphylococcus aureus as normal flora of human skin and opportunistic microorganism, and Escherichia coli as indicative organisms for fecal contamination/ poor sanitary conditions.

\section{Conclusion}

This study has demonstrated the effect of inclusion of different levels of pumpkin seed flour (PSF) into wheat flour on the nutritional and microbiological qualities of pumpkin (Cucurbita pepo) seed composite flours. The protein, fat, ash, and crude fiber contents of the blends improved with the inclusion of PSF while moisture and carbohydrates contents reduced. The blended flours showed good proximate, mineral and peroxide contents that resulted in high quality composite flours. Due to the high nutritional contents and reduced microbial counts of the blends, inclusion of pumpkin seed flour in supplemented products should be encouraged so as to enhance nutritional requirements and eradicate malnutrition among individuals especially infants and children.

\section{Compliance with ethical standards}

\section{Acknowledgments}

The authors are grateful to every contributor.

\section{Disclosure of conflict of interest}

No conflict of interest.

\section{References}

[1] Younis YMH, Ghirmy S and Al-Shihry SS. (2000). African Cucurbita pepo L: Properties of seed and variability in fatty acid composition of seed oil. Phytochemistry, 54, 71-75.

[2] El-Adawy TA. (2001). Characteristics and composition of watermelon, pumpkin, and paprika seed oils and flours. Journal of Agricultural and Food Chemistry, 49, 1253- 1259.

[3] Mohamed IO. (2003). In vitro bioavailability of minerals in selected tropical fruits and vegetables. M. Sc. Thesis, University of Khartoum, Sudan.

[4] Chung KH, Shin KO, Hwang HJ and Choi KS. (2013). Chemical composition of nuts and seeds sold in Korea. Nutrition Resource Practice, 7, 82-88.

[5] Sicilia T, Niemeyer HB, Honig DM and Metzler M. (2003). Identification and stereochemical characterization of lignans in flaxseed and pumpkin seeds. Journal of Agricultural and Food Chemistry, 51, 1181-1188.

[6] Ike CC, Emeka-Ike PC, Nwokorie CC and Anochie CC. (2015). Microbiological quality evaluation of locally prepared snacks sold in Aba metropolis, Abia State, Nigeria. International Journal of Scientific Engineering and Applied Science (IJSEAS), 1(7), 46-59.

[7] Idouraine A, Khan MJ, Kohlhepp EA, Weber CW, Warid WA andMalrinez- Tollez JI. (1996). Nutrient constituents from light lines of naked squash (Cucurbita pepo L.). Journal of Agriculture and Food Chemistry, 44(3), 721-724. 
[8] Nkosi CZ, Opoku AR and Terblanche SE. (2006). Antioxidative effects of pumpkin seed (Cucurbitapepo) protein isolate in $\mathrm{CCL}_{4}$ induced liver injury in low protein fed rats. PhytotherapyReserach, 20, 935-40.

[9] Dhiman. (2009). African Cucurbitapepo. Properties of seed and variability in fatty acid composition of seed oil. Journal of Phytochemistry, 54(1), 71-75.

[10] Ike CC and Emeka-Ike PC. (2016). Bacteriological Quality of Processed African Oil Bean Seed (Pentaclethra macrophylla) sold in Umulolo and Ihube Communities in Okigwe, Imo State, Nigeria. International Journal of Scientific Engineering and Applied Science (IJSEAS), 2(5), 126-136.

[11] Ptitchkina NM, Novokreschonova LV, Piskunova GV and Morris ER. (1998). Large enhancements in loaf volume and organoleptic acceptability of wheat bread by small additions of pumpkin powder: Possible role of acetylated pectin in stabilizing gas-cell structure. Food Hydrocolloids, 12, 333-337.

[12] Gajigo 0 and Lukoma A. (2011). Infrastructure and agricultural productivity in Africa: Market brief, AFDB (African Development Fund).

[13] Barkema A. (1993). Reaching consumers in the twenty first century: The short way around the barn. American Journal Agricultural Economics, 75(5), 1126-1131.

[14] AOAC. (2012). Official methods of analysis, Association of official analytical chemist 19th edition, Washington D.C., USA.

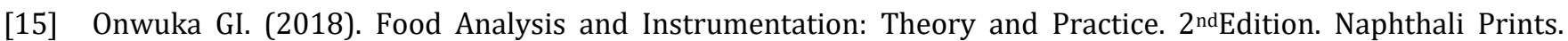
Surulere, Lagos Nigeria, 146-161.

[16] Cappucino GJR and Sherman B. (2010). Microbiology: A Laboratory Manual, 9th Edition. The Benjamin Publishing Company. California.

[17] Boone DR, Castenholz RW, Garrity GM, Brenner DJ, Krieg NR and Staley JR (Eds.). (2005). Bergey's Manual of Systematic Bacteriology. Second Edition. New York: Springer Verlag.

[18] Kidd S, Halliday C, Alexiou H and Ellis D. (2016). Description of Medical Fungi. $3^{\text {rd }}$ Edition. Newstlye Printing. Adelaide, South Australia 5031, Australia, 23-170.

[19] Ocheme OB, Adedeji OE, Chinma CE, Yakubu CM and Ajibo UH. (2018). Proximate composition, functional, and pasting properties of wheat and groundnut protein concentrate flour blends. Food Science and Nutrition, 6, 1173-1178.

[20] Hamed SY, El-Hassan NM, Hassan AB, Eltayed MM and Babikar EE. (2008). Nutritional evaluation and physiochemical properties of processed pumpkin (Telfairia occidentalis Hook) seed flour. Pakistan Journal of Nutrition, 7, 330-34.

[21] Abd El-Ghany MA, Dalia AH and Soha MS. (2010). Biological study on the effect of pumpkin seeds and zinc on reproductive potential of male rats. Proceedings of 5th Arab and 2nd International Annual Scientific Conference, 2384-2404.

[22] Kim MY, Kim EJ, Kim YN, Choi C and Lee BH. (2012). Comparison of the chemical compositions and nutritive values of various pumpkin (Cucurbitaceae) species and parts. Nutrution Research and Practice, 6, 21-27.

[23] Elinge CM, Muhammad A, Atiku FA, Itodu AU, Peni IJ, Sanni OM and Mbongo AN. (2012). Proximate, mineral and anti-nutrient composition of pumpkin (Cucurbita pepo L) seeds extract. International Journal of Plant Research, 2(5), 146-150.

[24] Milovanovic MM, Demin MA, Vucelic-Radovic BV, Žarkovic BM and Stikic RI. (2014). Evaluation of the nutritional quality of wheat bread Prepared with quinoa, buckwheat and pumpkin seed blends. Journal of Agricultural Sciences, 59(3), 319-328.

[25] Manpreet K. (2017). Development and nutritional evaluation of pumpkin seed (Cucurbita moschata) supplemented products. Unpublished M.Sc. Thesis, Department of Food and Nutrition, College of Home Science, Punjab Agricultural University, Ludhiana-141004, 1-89.

[26] Wongsagonsup R, Kittisuban P, Yaowalak A and Suphantharika M. (2015). Physical and sensory qualities of composite wheat-pumpkin flour bread with addition of hydrocolloids. International Food Research Journal, 22(2), 745-752.

[27] Iwe MO, Onyeukwu U and Agiriga AN. (2016). Proximate, functional and pasting properties of FARO 44 rice, African yam bean and brown cowpea seeds composite flour. Cogent Food and Agriculture,2, 1-10. 
[28] El-Adawy TA and Taha KM. (2001), Characteristics and composition of watermelon, pumpkin and paprika seed oils and flours. Journal of Agriculture, Food and Chemistry, 49, 1253-1259.

[29] Noor-Aziah AA and Komathi CA. (2009). Physicochemical and functional properties of peeled and unpeeled pumpkin flour. Journal of Food Science, 74, S328-S333.

[30] Omotoso OT. (2006). Nutritional quality, functional properties and antinutrients compositions of the larva of Cirinaforda (Westwood) (Lepidoptera satuniidae). Journal of Zhejiang University of Science, 7, 51-55.

[31] Gibney MJ. (1989). Nutrition diet and health. New York, NY, Cambridge University Press. 168.

[32] Emeka-Ike PC. (2020). Potentials of wheat and pumpkin (cucurbita pepo) seed composite flours in cake making. Unpublished M.Sc. Thesis, Department of Food and Technology, Faculty of Engineering, Imo State University, Owerri, 1-124.

[33] Gernah DI, Ariahu CC and Ingbian EK. (2011). Effects of malting and lactic fermentation on some chemical and functional properties of maize. The American Journal of Food Technology, 6, 404-412.

[34] Araujo RGO, Pimentel MF, Macedo SM, Bruns RE, Korn M, da GA and Ferreira SLC. (2008). Mineral composition of wheat flour consumed in Brazilian cities. Journal of Brazilian Chemical Society, 19(5), 935-942.

[35] Farzana C, Deshpande B and Begum MJ. (2003). Nutritional components of wheat products. Indian Journal Nutrution and Dietetics, 40,141- 46.

[36] Manpreet K and Sonika S. (2018). Development and nutritional evaluation of cake supplemented with pumpkin seed flour. Asian Journal of Dairy and Food Research, 37(3), 232-236.

[37] Fawzi WW and Hunter DJ. (1998). Vitamins in HIV disease progression and vertical transmission. Epidemiology, 9, 457-466.

[38] Gibson RS. (2003). Inadequate Intakes of Zinc in developing countries - Practical household strategies to reduce risk of deficiency, Zinc and Human Health.

[39] Latunde-Dada OG. (2000). Women and sustainable approaches to the management of iron deficiency. Food and Nutrition Bulletin, 21, 277-278.

[40] Adeel R, Sohail A and Masud T. (2014). Characterization and antibacterial study of pumpkin seed oil. Life Science Leaflets, 49, 53-64.

[41] Jay MJ, Loessner MJ and Golden DA. (2005). Modern Food Microbiology, Seventh Edition. Springer Publishers, USA, 39-60.

[42] Barber L, Ibiama EA and Achinewhu SC. (1989). Technical note: Microorganisms associated with fermented fluted pumpkin seeds (Telferia occidentalis). International Journal of Food Science and Technology, 24, 189-193.

[43] Emeka-Ike PC, Ike CC, Nwokorie CC and Ogwuegbu HO. (2019). Food safety processing and evaluation of powdered pap from maize and malted maize with carrot. Elixir International Journal - Elixir Food Science,132, 53452-53457. 